\title{
Towards a linguistic theory of translation as re-contextualisation and a Third Space phenomenon
}

\author{
Juliane House \\ University of Hamburg
}

The article suggests a theory of translation as re-contextualisation and a 'Third Space' phenomenon supplementing the ideas recently suggested in the cultural branch of translation studies with a linguistic account and building a bridge between the two. The view proposed here is rooted in a functional approach to translation. Such an approach is fruitful because it implies a systematic consideration of the context of translation units and the embeddedness of language as a meaning-making tool in microsituational and macro-sociocultural contexts. The categorically different nature of Third Space in covert and overt translation is exemplified and explained with reference to House's theory of translation as recontextualisation. Finally, possible changes in conceptualizing translation as a Third Space phenomenon are mentioned with a view to the growing dominance of English as a global lingua franca.

\section{Introduction}

In this article I want to sketch a theory of translation as re-contextualisation and a 'Third Space' phenomenon. My assumption is that a translation is not, and indeed cannot be, part of the original text's lingua-cultural context, its context of situation, nor does it fully belong to the receiving linguacultural context. In some sense, then, a translation will always be 'different', marginal, located in-between, in short, existing in Third Space. This description is, of course, in line with mainstream ideas in the cultural (including literary) branch of translation studies, and is thus nothing new. New is, however, the idea of a linguistically motivated approach to looking at translation as a phenomenon of Third Space. Such an idea might serve to 'build bridges' between the cultural and the linguistic approaches to translation. I will argue that one way of bridge building and mediating between the increasingly divergent roles literary, cultural and linguistic approaches to translation and meaning making have come to play is to consistently adopt a functional view of translation. Such an approach is fruitful because it implies a systematic consideration of the context of translation units and the embeddedness of language as a meaning-making tool in micro-situational and macro-sociocultural contexts.

Consequently, this account of the re-contextualized Third Space nature of translation is different from the Third Space famously suggested by 
Bhabha $(1990,1994)$ - which is taken up in translation studies by Wolf (2000) and Batchelor (2008) - because it recognizes that Third Space in translation differs categorically according as the translation follows two distinct procedures: covert and overt. In the covert variety, it is the in principle imperfect application of a so-called "cultural filter" which causes translations to hover in Third Space. In the overt procedure, it is not so much cultural, but rather linguistic expression differences which push translation into third space. In both cases, however, we are faced with a residual strangeness, something that confirms the age-old traduttore-tradittore adage (see e.g. Clifford 1997: 42). I will substantiate this claim by relating it to my own theory of translation re-contextualisation. In conclusion, I will briefly discuss how global English may now critically affect processes of re-contextualisation in translation such that text conventions in linguacultural communities around the world are about to change as translations (and other texts) are pushed into Anglophone First Space.

\section{Building Bridges between Cultural and Linguistic Approaches to Translation}

In recent decades, we have witnessed a shift in translation studies from linguistically-oriented approaches to culturally-oriented ones. It is thus appropriate to speak of a "cultural turn" in translation studies. The cultural approach to translation is epitomized in statements such as "one does not translate languages but cultures" or "communicating across linguistic borders means bridging cultures". How did this shift to a cultural view of translation come about? The explanation is simple: translation, I would suggest, has here simply followed a general trend in the humanities and social sciences, where contents and methodologies have over the past decades been strongly influenced by post-modernist, post-colonial, feminist and other socio-politically, psychologically and philosophically motivated schools of thought. It would be strange indeed if translation were an exception in this regard.

But culture need not be dichotomously juxtaposed to language because culture and language cannot really be separated. A non-bipolar way of taking account of "culture" in translation might for instance follow the model set for some time by various functionally oriented linguistic schools such as the Prague school of linguistics, or the British contextualist school of systemic functionalism - schools where language has long been conceived as primarily a sociocultural phenomenon which is naturally and inextricably intertwined with social situations and culture such that the meaning of any linguistic and, by extension, any translation, item can only be properly understood with reference to the cultural context enveloping it. Since in translation 'meaning' is of particular importance, it follows that translation cannot be understood outside a cultural frame of reference. Adherents of such an integrative view of language and culture in translation 
theory (e.g. Koller 1995; House 1997; Steiner and Yallop 2001), while regarding translation as a particular type of socio-culturally determined practice, also hold that translation is, at its core, a linguistic procedure. Such a view differs significantly from the radical cultural studies view where translation is taken to be prominently, or even exclusively, culture-related.

If one wants to bridge the gap between the cultural studies and the linguistics perspectives on translation aiming at an integrative approach,

one must, it seems to me, first define one's terms: 'culture', the related issues of 'linguistic and cultural relativity' and 'context'. It is to these concepts that I will now turn.

\section{Culture and linguistic-cultural relativity}

"Culture" has been the concern of many different disciplines from philosophy, sociology, anthropology, literature to cultural studies, and the definitions offered in these fields vary according to the particular frame of reference invoked. Two basic views of culture can however be said to have emerged: the humanistic concept of culture and the anthropological one. The humanistic concept of culture captures the "cultural heritage" as a model of refinement and an exclusive collection of a community's masterpieces in literature, fine arts, music etc. The anthropological concept of culture refers to the overall way of life of a community, i.e., all those traditional, explicit and implicit designs for living which act as potential guides for group members' behavioural patterns. Culture in the anthropological sense of a group's dominant, acquired and accepted sets of habits, as the totality of its non-biological inheritance involves presuppositions, preferences and values - all of which tend to be neither easily accessible nor verifiable. In what follows, the anthropological view of culture will be pursued because it is a broader concept and one which lends itself more easily to being applied to translation studies.

Inside the anthropological frame of culture, four analytical levels on which culture is to be characterized can be differentiated (see House 2001b for a more extensive discussion, and House 2005 for a comparable description of politeness as localisable on various levels). Firstly the general human level, along which human beings biologically and societally differ from animals: human beings unlike animals are capable of creatively shaping and changing the environment into which they are born. The second level is the societal, national (sometimes super-national) level, culture being the unifying force which enables human beings to position themselves vis $\grave{a}$ vis systems of government, domains of activities, religious beliefs and values in which human thinking expresses itself. The third level corresponds to the second one but captures various societal and national subgroups according to geographical region, social class, age, sex, professional activity and topic. The fourth level is the personal, the individual one relating to an individual's guidelines of thinking and acting. This is the level of cultural 
consciousness, which enables a human being to be aware of what characterizes his or her own culture and makes it distinct from others.

Given these levels which integrate human, social and individual perspectives, the concept of culture can be (informally) defined as whatever a member of a culture - in whatever role he or she chooses to adopt - has to know or believe such that he or she is enabled to operate in a manner acceptable to other members. Culture is thus not only a material phenomenon; it does not consist of things, people, behaviour, or emotions. It is rather the overall organization of all these facets of life, which culture members have internalized, are led to perceive, connect and interpret.

This definition stresses some sort of cognitive-social unity of a group's orientation, a view which has however recently been heavily criticized (cf. e.g. Gupta \& Ferguson 1997; Holliday 1999, and, with an application to translation, see e.g. Venuti 1995; Robinson 1997), such that the whole notion of 'culture' has come under attack. The critique formulated in post-modernist cultural studies circles can be summarized as follows: the very idea of "culture" is an unacceptable abstraction, there are no "pure cultures", and there are no such things as "social groups" because groups are constantly destabilized by external influences, individual idiosyncrasies in thought and action, with identities becoming fluid, dynamic and open to adjustment and change. Cultures themselves are, in this view, mere ideologies, idealized systems simply serving to reduce real differences that always exist between human beings in particular socially and geographically delimited areas (cf. e.g. Calzada Perez 2003). Is the very concept of a community's "culture" therefore useless, in particular for such an eminently practice-oriented field as translation? I believe not. In the empirical social sciences, attempts to radically "relativise" the concept of "culture" have, as far as I can see, as yet not prevented solid ethnographic descriptions of entities such as 'cultures'. Moreover, if such criticism were taken to its logical conclusion by social scientists, their field of inquiry would no longer exist. For translation and for the practical business of analysing and comparing originals and translations, as well as producing translated texts, it is more appropriate to look upon culture as locally exemplified in texts and discourses - and this necessarily makes 'culture' to a certain degree "essentialist" and "reified" - in a very real (and positive!) sense of these words.

One recent approach which seems to me particularly well suited to resolve the hotly debated issue of generalization versus diversification, and individualization of cultures is the one suggested by Sperber (1996). He views culture in terms of different types of "representations" (of ideas, behaviours, attitudes, values etc.). Within any cultural group a multitude of individual "mental representations" exist, most of which are fleeting and individual. A subset of these representations, however, can be overtly expressed in language and artefacts. They become "public representations", which are communicated to others in the social group. This communication gives rise to similar mental representations in others, which, in turn, may be communicated as public representations to others that may again be com- 
municated to different persons involving mental representations and so forth. If a subset of public representations is communicated frequently enough within a particular social group, these representations may become firmly entrenched and turn into "cultural representations". The point at which a mental representation becomes sufficiently widespread to be called "cultural" is, however, still a matter of degree and interpretation - there is no clear division between mental, public, and cultural representations.

Members of a particular culture are constantly being influenced by public and cultural representations (with regard to values, norms, traditions etc.). This influence is exerted most prominently through the language used by members of the society in communication with other members. Language as the single most important means of communicating, of transmitting information and providing human bonding has therefore an outstanding position inside any culture. Language is the prime means of an individual's acquiring knowledge of the world, of transmitting mental representations and making them public and intersubjectively accessible. Language is thus the most important instrument of a "collective knowledge reservoir" to be passed on from generation to generation. But language also acts as a means of categorizing cultural experience, thought and behaviour for its speakers. Language and Culture are therefore closely interrelated on the levels of semantics, where the vocabulary of a language reflects the culture shared by its speakers.

As opposed to this view that language "reflects" a group's culture, the ideas which came to be known as "linguistic relativity" imply the very opposite: language in its lexicon and structure has an influence on its speakers' thinking, their "worldview" and behaviour. The idea that an individual's mother tongue is an important source of cognitive and behavioural conditioning goes back to German idealistic philosophy and was most prominently formulated by Herder and von Humboldt, who propagated the view that every language as an a priori framework of cognition determines its speakers' "Weltanschauung". The 'spiritual structure' of a language is assumed to correspond to the thought processes of its users, language being situated at the interface between objective reality and man's conceptualization of it. The relativity postulate put forward in the first half of the twentieth century particularly by Benjamin Lee Whorf advanced basically similar ideas. Whorf in particular inferred mental and behavioural differences from differences between languages on the levels of lexis and syntax.

The consequence of the linguistic relativity postulate for translation is the denial of its theoretical possibility - "theoretical" because the age-old practice of translation obviously denies this claim. The apparent contradiction between assumption and reality can, however, be resolved when one considers that linguistic relativity, though clearly affecting, in specified areas, some of our cognitive behaviour, can always be counteracted through language itself and its users' creativity, dynamism and flexibility. Further, it is necessary to also link linguistic diversity to external differences of historical, social and cultural background rather than one-sidedly insisting on 
the overriding importance of a link between cognitive and linguistic differences. If we consider that languages are structured in divergent ways because they embody different conventions, experiences and values, then the importance of what may be called linguistic-cultural relativity emerges. Such a notion of relativity is much more relevant for translation (see House 2000 for a detailed discussion). Cultural knowledge, including knowledge of various subcultures, has long been recognized as indispensable for translation, as it is knowledge of the application which linguistic units have in particular situational and socio-cultural contexts which makes translation possible in the first place. 'Application' here refers to the relation holding between an expression and the cultural situation in which it is used - it is pragmatic meaning. In establishing equivalences between source and target linguistic units in translation, the notion of "application" is crucial: if sense and reference differ for two linguistic units, it is their application in particular knowable and describable cultural contexts that ensures translatability. Linguistic units, as argued above, can never be fully understood in isolation from the particular cultural phenomena for which they are symbols.

While differences in the "worldviews" of speakers of different languages leading to different concepts in their minds may never be accessible to translators, the intersubjectively accessible application of linguistic units in a particular situation can. And even if cultural distances between languages are great, cultural gaps can, in theory, be bridged via ethnographic knowledge. Conceptions of language within the broader context of culture, in which meaning is regarded as contextually determined, are by no means recent developments. They have a venerable tradition in inter alia Russian Formalism, Prague School, systemic functionalism, the sociology of language, speech act theory and discourse analysis, and they have been used to construct a functional theory of translation as re-contextualisation to be described in the following section. I can also see a similarity of the notion of "worldview" to what is called 'ideology' by several translation scholars (see e.g. Hermans 1985, Mason 1994 and Hatim and Mason 1997).

\section{Translation as a phenomenon of re-contextualisation and 'Third Space'}

For a theory of translation to achieve descriptive and explanatory adequacy, a conception of language as cognitively directed "text-in-function", "textin-communication", "text-in-situation" (the micro-perspective) and as "text in culture" (the macro-perspective) is essential. Translation is thus an event rooted in a communicative and cultural situation. To describe and explain this event, communication must be understood as cognito-social action between two or more participants. Even in quasi-monologous written linguistic products ("texts"), where participants do not share the same spatiotemporal framework, they are clearly involved. Each communicative event 
is intentional, and it is (pre)determined by participants' knowledge. The addressees of a written text are also involved in its production because of the text producer's cognitive act of anticipation and because of the subsequent act of interpretation in which the original communicative situation is re-enacted, triggered by the linguistic forms and their particular arrangement. Language-in-communication is intentional, cognito-social action that always takes place in situations, in which language users communicate either directly (as in oral hic-et-nunc-interactions) or indirectly (as in written interactions where participants are removed in space and time). This difference also has to do with our understanding of context. But what exactly do we mean by context?

The word context derives from the Latin verb texere, 'weave', with the related Latin verb contexere meaning 'to weave or join together'. Given this etymology, the word 'context' can be described as referring to the 'weaving together of words and sentences', and to the 'connection or coherence between parts of a discourse'. In a more general, figurative sense, context - as used, for instance, in phrases like 'the historical context', 'in this context' - refers to a general type of relationship or connection, such that the phrase 'in this context' can be rephrased as 'in this connection'. Here context can be taken to mean something like 'the circumstances relevant to something under consideration'. This latter sense of context implies the notion of an environment and of conditions surrounding a specified phenomenon or object (such as a text!), and also that these conditions can be taken to determine the meaning of this phenomenon or object. Context as something that both surrounds, and gives meaning to, phenomena and objects can further be related to concepts such as setting, background, and to Bateson's (1972) and Goffman's (1974) concept of frame as well as to the Gestalt theorists' notions of figure and ground. All these ideas invoke 'context' as the conditions for understanding the object(s) it surrounds.

Indeed, context relates both to external (situational and cultural) factors and/or to internal, cognitive factors, all of which interact in acts of speaking and listening. In many approaches, context - and its relationship with language - is regarded as essentially dynamic rather than static. Context is here more than a set of pre-fixed variables that impact on language, context and language being in a mutually reflexive relationship, such that language shapes context as much as context shapes language. Such a view of context is, I would submit, not useful for translation. True, translation is an act of language use, and it may well be conceptualized as a process of recontextualization, because in translating, stretches of language are not only given a new shape in a new language, but are also plucked from another context, placed in a new one with different values assigned to those communicative conventions, genres, readers' expectation norms which held for the original addressees - and also, critically, for the new recipients. What is of crucial importance in translation however is the undeniable fact that a 'finished', and in this sense 'static' stretch of written language as text is presented to the translator in its entirety from the start of her translation task 
- an exception being the increasing frequency of online texts which are constantly changing. The task of translating as re-contextualization consists of enacting a discourse out of the written text, i.e., the translator creates a 'living', but essentially not fully dynamic, cognito-social entity replete with new - third space - contextual connections. The targeted context in the recipient lingua-cultural context cannot be "dynamic" or "negotiated" in the traditional sense, firstly because of the power relationship implied by the connection between text and translator, and secondly because of the essential futility of ever seamlessly plugging the translation into the textual world of the target lingua-culture. In other words, the essentially 'static' quality of context in translation arises in the very space opened up by the separation in time and space of writer and reader, and by means of the ability (and responsibility) of the translator himself or herself to define what the context is - and place it in Third Space. This is very different from the type of context conventionally invoked in oral interaction, where spoken text is a direct reflection of the discourse enacted by (physically) co-present interactants, and where a discourse sequentially develops, directly and overtly involving speaker and hearer in turns-at-talk. For translation, the availability of a written text at once in its entirety (as opposed to the bit-by-bit unfolding of negotiable text and discourse) is constitutive. From this it follows that context in translation is not dynamic, as it solely and simply emerges from the translator's creatively imagining a virtual context - which is neither here nor there but in Third Space. True to the nature of written language, the realization of a discourse out of a text available in writing then involves imaginary, hidden interaction between writer and reader in the mind of translator, where the natural unity of speaker and listener in oral interaction must be imagined in the face of the real-world separateness in space and time of writer and reader, mirroring the in principle non-synchronous temporality of translation. The only way for the translator to overcome this separateness and create a new unity is to transcend the givenness of the text with its immutable arrangement of linguistic elements by activating its contextual connections, linking it to both its old and its new context, which a translator mentally unites creating meanings anew. The outcome of this imaginative linking feat necessitated by the nature of written language with its built-in temporal and spatial constraints is the placing of the text in Third Space thus acknowledging the incommensurable differences of time and space - and context. The notion of "Third Space" invoked here is clearly in line with the Third Space notion famously outlined by Bhabha (1994: 36):

The reason a cultural text or system of meaning cannot be sufficient unto itself is that the act of cultural enunciation - the place of utterance - is crossed by the différance of writing. This has less to do with what antropologists might describe as varying attitudes to symbolic systems within different cultures than with the structure of symbolic representation itself[...] It is this difference in the process of language that is crucial to the production of meaning and ensures, 
at the same time, that meaning is never simply mimetic and transparent. The linguistic difference that informs any cultural performance is dramatized in the common semiotic account of the disjuncture between the subject of a proposition (énoncé) and the subject of enunciation, which is not represented in the statement but which is the acknowledgement of its discursive embeddedness and address, its cultural positionality, its reference to a present time and a specific space[...] The production of meaning requires that these two places be mobilized in the passage through a Third Space, which represents both the general conditions of language and the specific implication of the utterance in a performative and institutional strategy of which it cannot in itself be conscious.

If we substitute in the above quote "translation" for "utterance" and "enunciation", we can see that Bhabha's understanding of the role of Third Space in meaning making is relevant for what happens in translation, in that it stresses the intervention of the Third Space of enunciation (translation) and renders the construction of meaning as an ambivalent process. It is the disruptive temporality and locality inherent in all translation which accounts for its displacement into Third Space. As mentioned above, the notion of Third Space has been adapted to translation by culturally oriented translation scholars such as Wolf (2000). She has recently been criticised as having misunderstood and inappropriately simplified Bhabha by Baker (2007) and Batchelor (2008). Batchelor rightly suggests a re-location of the concept of Third Space away from a simple spatially defined "in between" to a more temporally and abstract conception where "the failure of translations to fully contain and control the originals that they bring into being" (Batchelor 2008: 64) is emphasized.

For a theory of translation as Third Space re-contextualization to achieve descriptive and explanatory adequacy it is necessary to treat context as a means of converting "inert text" (Widdowson 2004: 8) into discourse in an ex post facto process of positioning the text in the "context of situation" (Malinowski 1935). The notion of a 'context of situation' developed in systemic-functional theory by Halliday and his collaborators (cf. most recently Halliday and Matthiessen 2004) - is useful for a theory of translation as re-contextualization, and indeed for the theoretical possibility of translation. Whenever communication is possible between speakers of the same language, it is also possible between speakers of different languages, and for the same fundamental reasons: through relating linguistic units to the enveloping context of situation and through analysing common situations and identifying those whose distinctive and unfamiliar features are peculiar, such that they can be known, interpreted and re-contextualized in the minds of translators. Given, however, the necessarily subjective, idiosyncratic nature of the translator's mental actions, it is not a new 'real' context of situation but a Third Space which a translation is confined to inhabit. Such a view of translation as an act of re-contextualization and its locus in 
third space is further developed below, where a theory of translation as recontextualization and a third space phenomenon is described.

\section{A functional theory of translation as Third Space re- contextualisation}

In translating, a given text in one language is to be replaced by a functionally equivalent text in another language. Functional equivalence is thus a key notion in translation. It can be established (and evaluated) by referring original and translation to the "context of situation" enveloping original and translation, and by examining the interplay of different contextual factors or dimensions shaping the text (House 1977, 1997). The dimensions are used to "open up" the text such that its textual profile, which characterizes its function, can be revealed. In order to determine the function of a text, consisting of an interpersonal and an ideational functional component which must be kept equivalent in translation, the text is analysed at the levels of Language, Register and Genre. The relationship between these levels can be seen in terms of semiotic planes which relate to one another in a Hjemslevian 'content-expression' way, with Genre being the content-plane of Register, and Register being the expression plane of Genre. Register in turn is the content-plane of Language, and Language is the expression plane of Register. Register is divided in Hallidayan fashion into Field, Tenor and Mode. Field refers to the subject matter and the nature of the social action handled in the text. Along Tenor, the author's temporal, geographical, and social provenance is diagnosed, as is the author's intellectual and emotional stance (his/her 'personal viewpoint') vis à vis the content s/he is portraying and the communicative task $\mathrm{s} / \mathrm{he}$ is engaged in. Tenor also captures the social role relationship between author and addressee(s), and between fictive characters in the text as well as the "social attitude" adopted, i.e., formal, consultative and informal style levels manifest in the text. Along Mode, Biber's (1988) distinctions between involved versus informational text production, explicit versus situation dependent reference, and abstract versus non-abstract presentation of information are taken into account. Establishing linguistic-textual correlates of Register, i.e., Field, Mode and Tenor, and of the Genre they realize - with Genre being understood as reflecting the communicative purpose shared by a collectivity of texts yields a certain textual profile characterizing its textual function, which is to be kept equivalent in translation. Genre and Register thus cover different aspects of the adaptation of language to the demands of its social use: Registers are conglomerates of linguistic features in response to situational parameters, Genres are types of linguistic objects. As linguistic objects the texts which constitute a Genre can be considered from a static or a dynamic perspective.

Equivalence of function, however, differs markedly in two empirically derived (House 1977) types of translation, overt and covert transla- 
tion. Distinguishing these two translational types is thus indispensable in any discussion of functional equivalence. The distinction of these two translation types is reminiscent of Schleiermacher's classic distinction between "einbürgernde" versus "verfremdende Übersetzung", a critical difference being, however, that the covert-overt distinction is tied to a well-argued theory of translation and translation criticism. A translation typology is stronger in explanatory adequacy than a traditional text typology when it comes to describing and judging the different processes of translation involved in handling culture-specific phenomena in the two language communities. In other words, the claim is that in order to resolve the crucial conflict in translation between universality and culture specificity, the distinction of two basic translation types, overt and covert translation may prove insightful.

An overt translation is, as the name suggest overtly a translation, not as it were a second original, hence its new addressees are quite "overtly" not directly addressed. In an overt translation, the original is tied in a specific way to the culture enveloping it; it has independent status in the source culture, and is both culture-specific and pointing beyond the source culture because the original text is also of potential general human interest. Although timeless and transmitting a general human message, texts that call for overt translation, are at the same time culture-specific because they tend to reflect a geographical or social variety and because they have independent status in the language community through belonging to the community's cultural products. Many such texts are literary texts and can be characterized by their fictional nature, i.e., they are situationally abstract in that they do not immediately refer to a unique historic situation. Fictional texts describe a fictive reality which is, in every reception by an individual reader, newly related to the specific historic reality in the concrete situation in which the reader finds himself. The message in a fictional text is emic, it presupposes no wider context so that everything necessary for its interpretation can in principle be found within the message itself - and this is what gives the literary text its independent - indeed its culturally universal feature. This self-sufficiency might also explain why such texts can more easily be transferred in toto through space, time and cultures - and this despite the fact that those texts may well be heavily marked for culture-specific regional or social varieties.

The language in overt translation is for Schleiermacher interspersed with foreign elements coming from the original such that in the overt translation we see and feel "die Spuren der Mühe aufgedrückt" [the traces of the effort superimposed on it] (1973: 45). So overt translations are texts which are in many aspects similar to their originals, but in decisive aspects - just because of this closeness - not at all similar to the original and not at all comparable. And it is here that translation theorists of the $20^{\text {th }}$ century have linked up with Schleiermacher. Thus Walter Benjamin writes: 
Es ist daher [...] das höchste Lob einer Übersetzung nicht, sich wie ein Original ihrer Sprache zu lesen.. Die wahre Übersetzung ist durchscheinend, sie verdeckt nicht das Original, steht ihm nicht im Licht [...] (1972:9)

[It is therefore...not the highest praise of a translation that it reads like an original of its language. The true translation is one that is shimmering through, it does not hide the original, it does not stand in its light] (translation $\mathrm{JH}$ )

And Ortega y Gasset (1965) goes as far as claiming that when translating in any other way than overtly, one does not really translate at all. We only, he says, produce an imitation or a paraphrase of the original. Only when readers are being torn away from their linguistic habits and when they are being forced to imagine the linguistic habits of the author, can we speak of a translation proper, an "eigentliche Übersetzung" [a translation proper] in Koller's (1995) words.

An overt translation is embedded in a new speech event in the target culture: it operates in a new frame, a new "discourse world", and it is a case of "language mention" resembling a quotation or citation. In terms of the translation theory presented above, an original and its overt translation are equivalent at the levels of Language and Register as well as Genre. At the level of the individual textual function, however, "true" functional equivalence, is not possible. At best, an equivalence of a "removed" nature, a sort of shifted equivalence at Third Space can be achieved: its function is to enable access to the function which the original has (had) in its discourse world or frame. As this access must of necessity be realized in the target lingua-culture via the translation, a switch in the discourse world becomes necessary, i.e., the translation operates in its own discourse world, and can thus reach only a sort of topicalization of the original's textual function. Paradoxically, this type of functional equivalence is achieved through an equivalence at all the three analytical levels, i.e. Language/Text, Register, Genre, which together facilitate the co-activation of the source text's frame and discourse world. It is through this co-activation of both discourse worlds and frames that members of the target cultural and linguistic community are put in a position to "eavesdrop", as it were, i.e., they are enabled to appreciate the function the original text has - albeit at a - linguistic and cultural - distance at Third Space. In tackling an overt translation, the translator must therefore quite "overtly" produce a translation which allows culturally different persons to gain an impression of, and "feel" for, the cultural impact that the original text has on source culture members, permitting them to observe and be worked upon by the original text. In the case of overt translation, we can speak with some justification of genuine cultural transfer. Transfer is here understood as a result of a contact situation which results in deviations from the norm of the target language/ culture through the influence of another language and culture. This means that in overt translation, cultural transfer is often noticeable as a (deliberately) jarring 
difference (in Benjamin's sense) and deviation of the translation from target cultural norms, and it is this deviation which justifies claiming this transfer to be one at Third Space. Given this description, an overt translation is both from a linguistic and a psycholinguistic perspective a hybrid entity.

The situation is very different in the case of covert translation. A covert translation is a translation which enjoys the status of an original text in the receiving culture. The translation is covert because it is not marked pragmatically as a translation at all, but may, conceivably, have been created in its own right. A covert translation is thus a translation whose original is, in terms of status not particularly tied to the target culture. An original and its covert translation are - one might say - "universal" in the sense that they differ "only" accidentally in their respective languages. While it is thus clear that certain texts designed for "ready consumption", ephemeral and transitory texts, such as e.g. instructions, commercial circulars, advertisements, and other "pragmatic texts" such as journalistic and scientific texts, are not culture-bound, it is the covert type of translation such texts (normally) require which presents much more subtle and intricate cultural translation problems than overt translation. In order to meet the needs of the new addressees in their cultural setting, the translator must take the different cultural presuppositions in the two cultures into account, re-create an equivalent speech event and reproduce in the translation the function the original has in its linguistic-cultural framework, i.e., "real" functional equivalence is aimed at, and often achieved in covert translation. A covert translation operates quite "overtly" in the different frame and discourse world set up by the target culture without, however, wishing to co-activate the discourse world in which the original had unfolded. Covert translation is thus at the same time psycho-linguistically less complex than overt translation and more deceptive. It often results in a very real cultural distance from the original text, since the original is transmuted in varying degrees, and it is the translator's task to "cheat", as it were, and to remain hidden behind his feat of deception regarding the origin of the text produced. Since true functional equivalence is aimed at, changes at the levels of Language/Text and Register may, if necessary, be freely undertaken, and the result may be a very different text, which is the reason for the fact that covert translations are often received as though they were original texts. But they are not, they are texts in Third Space.

In aiming at "originality" in covert translation, the translator will employ a so-called cultural filter. With the use of this filter, the translator can make systematic allowances for culture specificity accommodating for differences in socio-cultural norms and differences in conventions of text production and communicative preferences. This cultural filter is thus the means with which the translator tries to compensate for the culture specificity that is foreign to the target community. The concept of a cultural filter is the core of covert translation. In any translating task translators are faced with subtle differences in cultural preferences, mentalities and values that need to be known for a covert translation and for the application of a cul- 
tural filter. Such knowledge should be based on empirical research into language pair-specific cultural differences, the assumption being that research into culturally determined communicative preferences in two discourse communities can give more substance to the concept of a cultural filter than mere intuition and tacit native-speaker knowledge and understanding can. One example of such research involving English and German discourse are my own studies of German and English difference and commonalities in discourse conventions (for a summary of this research, see e.g. House 2006b). Research into discourse norms holding in different lingua-cultural communities adds substance to the notion of a cultural filter and it also implicitly suggest that linguistic differences in the realization of discourse phenomena may be taken to reflect deeper differences in cultural preference patterns and expectation norms at a conceptual-cognitive and emotive ("mentality") level. Still, we cannot claim that with the application of a cultural filter a translation ever achieves full functional equivalence, rather it will remain in Third Space - a foreign body in the context and in its old one from which it was removed.

\section{Some examples of translation as Third Space re-contextualisation}

In the following I will present a number of textual extracts from a variety of different genres to exemplify the operation of re-contextualization and Third Space in both overt and covert translation.

The first two examples are taken from Michael Bond's classic English children's book series, A Bear called Paddington, published in London in 1958, featuring a little bear called Paddington, translated as Paddington unser kleiner Bär [Paddington our little bear] by Brigitte von Mechow and Peter Kent in München in 1968. All the excerpts discussed below are part of a corpus of original and translated English and German children's books (cf. House 2001a; 2004b).

(1) (Mr Brown offers Paddington some biscuits)

"I'm sorry they haven't any marmalade ones, but they were the best I could get"

Hier gibt es eben nichts mit Marmelade!

[Here is nothing with marmalade!]

(2) Mr Gruber took Paddington into his shop and after offering him a seat...

Dann zog er den kleinen Bären in den Laden "Setz dich!" sagte er...

[Then he pulled the little bear into the shop "Sit down!" he said....] (Bond 1958: 16. German translation 1968: 18) 
In the covert translations (1) and (2), a cultural filter has been used, to alter the original's level of politeness in Paddington's interactions with people in his environment. The tenor of the German translation is less polite than is the case in the original. I cannot here deal with the notion of politeness in translation but refer the reader to relevant previous work (House 1998, 2005). Given that it is a teddy bear who is treated in the original with exquisite politeness, and that this is also marked in an English environment, a humorous undertone results, which is - together with the politeness - absent from the translation. This loss of politeness (and seriousness) vis à vis Paddington leads to another feature shared by all the translations of the Paddington books: infantilisation and sentimentalisation. We can see this in (2) where Paddington is called 'der kleine Bär' [the little bear] and not, as in the original 'Paddington'. The Third Space here is constructed as clearly different from both the original and an equivalent German text because it also implies a different understanding of children, childhood and the values associated with them - values presumably held by the translator. Note also that in (2) Paddington is addressed by the familiar form of the imperative. Given Paddington's characterisation as a dignified, serious and polite person in the context, the more polite form with 'Sie' would conform to readers' expectations about conventions. This form would have been more effective in terms of the exquisite combination of distance and politeness on the one hand and the inherently "familiar" figure of the cuddly teddy bear which creates the humour in the original. The context created is a product of the translator's imagination - and as such it neither reflects the English text's deliberate construction of a humorous children's book, nor does it fit the discourse world of equivalent German children's books. In short, it has landed in Third Space.

Further, in (1) the speech act Apology in the English original is changed into an assertion in the translation, and in (2) the speech act Offer is replaced by the Speech Act Request (with a high level of directness) in German, which again results in a reduction of politeness in Herr Gruber's utterance.

Example (3), with an excerpt from Penny Ives's Mrs Christmas (1990), translated by Ishel Eichler as Morgen kommt die Weihnachtsfrau [Tomorrow comes the Xmas woman], published in Hamburg in 1990 also shows cultural filtering which results in third space placing. The example is taken from the tale of "Mrs Xmas" who jumps in for Father Xmas who has fallen ill. The German translation fills out each paragraph in the book with additional details. These addenda are, however, not random: they all add to the seriousness of the crisis brought on by Father Xmas' illness and they spring from a desire to build up the role of Mrs Xmas as a larger than life substitute for Father Xmas. We have here an ideologically motivated attempt to show female independence, competence and superiority: another case of moving the translation into Third Space - into a feminist world of superiority of females over males. 
(3) "Just look at you" cried Mrs Xmas "You're all covered in spots. However will I finish making all these presents by myself? I'd better hurry up and find the reindeer

„Sieh dich nur an!” rief die Weihnachtsfrau „Du bist krank! Überall rote Pusteln! Wie soll ich denn ganz allein die vielen Geschenke fertig kriegen?" Der Weihnachtsmann schloss nur müde die Augen, er war sogar zu schwach, eine Antwort zu geben. „Das muss ich diesmal wohl tatsächlich allein schaffen. Weihnachten kann schließlich nicht einfach ausfallen,” murmelte die Weihnachtsfrau. „Erst mal geh ich zu den Rentieren, sie brauchen ihr Futter.

["Just look at you" cried the Xmas woman. "You are ill! Red spots all over the place! How on earth am I to finish all those presents all by myself?" Father Xmas just closed his eyes tiredly, he was even too weak to give an answer. "This time I must indeed manage all on my own. Xmas just can't be cancelled," murmured the Xmas woman. "First I will go to the reindeers, they need their food.] (Ives 1990: no pagination. German translation 1990: no pagination)

Example (3) shows how the covert translation provides answers to questions readers might have asked concerning conditions, motivations, thoughts and actions by actors represented in the text - all of which may or may not have been implied in the original. The translation is again removed into Third Space - a space where a certain type of reader is made concrete, specific, thereby limiting interpretative freedom.

Example (4) shows how another passage of this original is filtered, in this case again ideologically transformed, and thus shoved into Third Space:

(4) Finally she put on her red suit and hat. No one would recognize her now.

Am nächsten Morgen war es soweit: schon früh stand die Weihnachtsfrau auf, zog sich den roten Mantel an und setzte sich die Mütze an. Der Weihnachtsmann bekam noch einen Abschiedskuss ...

[Next morning was when it started: very early Mrs Xmas got up, put on the red coat and the hat. Father Xmas got a good bye kiss...] (Ives 1990: no pagination. German translation 1990: no pagination)

Why is the harmless sentence No one would recognize her now not translated, we may ask? Given the overall pattern of changes in this text, it is only logical that in the context of feminist ideology it is assumed to be undesirable that a strong woman is not also recognizable as such. There are 
many further places in this text which show how a harmlessly funny children's story is manipulated in the process of covert translation into a different discourse world of Third Space.

One final example from the genre of children's stories, Nele and Paul Maar's translation Hilfe die Herdmans kommen (1972) of Barbara Robinson's The Best Christmas Pageant Ever (1972) again shows cultural filtering - but of a different kind.

(5) (One of the Herdman children has a type of religious awakening)

She had walked into the corner of the choir-robe cabinet, in a kind of daze - as if she had just caught onto the idea of God, and the wonder of Christmas

Sie war in ihrer Benommenheit gegen den Schrank mit den Gesangbüchern gelaufen.

[In her daze she had walked against the cupboard with the hymn books.] (Robinson 1972: 79. German translation 1972: 93)

In excerpt (5) the allusion to God and the wonder of Xmas is not translated. This is consistent with the translation of the book's title which does not mention that the story is a Xmas story. The translation of the title and in fact of the whole book emphasizes the rebellious nature of the family portrayed in the book - the reason being that such a rebellion against authorities suits the ideology underlying the translation. Thus even the routine exclamation 'My God' is not translated into the equally routine German exclamation 'Mein Gott' [My God] but rather into the expletive 'Damned'. So here again we are faced with a translated text that occupies a new and different place in the text world - again a case of a Third Space translation.

In many other genres, too, we can see how translations are shunted to Third Space, deviating from their originals while at the same time not fitting in the respective receiving genres.

Consider example (6) taken from a detective novel, Dorothy Sayers The Nine Tailors (1934), translated as Der Glockenschlag by Otto Bayer (1978).

(6) "Everything very nicely done, Mr Russell," said Mrs Venables.

"Yes'm?" said Mr Russell. "Very glad you think so, 'm. We done what we could to the best of our ability." "I'm sure," said Mrs Venables, "that if his own people had been there, they couldn't have wished for anything nicer". "No'm," agreed Mr Russell, much gratified, "and it's a pity they couldn't a-been present, for there's no doubt a handsome funeral is a great comfort for them as is left. Of course, it ain't so grand as a London funeral would be -" He glanced wist- 
fully at Wimsey. "But much nicer," said Winsey in a ridiculous echo of Mrs Venables. "You see, it has so much more of the personal touch." "That's very true," said the undertaker, much encouraged. "Why, I dessay these London men get as much as three or four funerals every week...".

"Sie haben das alles sehr nett gemacht, Mr Russell," sagte Mrs Venables.

„Ja, Madam?” antwortete Mr Russell. „Es freut mich, daß Sie das sagen, Madam. Wir haben nach besten Kräften getan, was wir konnten."

„Ich glaube bestimmt” sagte Mrs Venables „daß seine eigenen Angehörigen es sich nicht schöner hätten wünschen können, wenn sie hier gewesen wären".

„Sicher nicht, Madam” pflichtete Mr Russell ihr sehr zufrieden bei, ,und schade ist es, dass sie nicht da sein konnten, denn so ein schönes Begräbnis ist für die Hinterbliebenen immer ein großer Trost. Natürlich sind unsere Beerdigungen nicht so prachtvoll wie vielleicht in London -" Mit einem erwartungsvollen Blick zu Wimsey. „Dafür aber viel netter” plapperte dieser Mrs Venables nach. „Hier hat noch alles so etwas Persönliches.” „Sehr wahr” pflichtete der Bestattungsunternehmer ihm sichtlich erleichtert bei. „Na ja, die Leute in London haben sicher jede Woche drei oder vier Beerdigungen."

["You have done everything very nice, Mr Russell," said Mrs Venables. "Yes, Madam? It makes me glad that you say this, Madam. We have done with all our might what we can. I certainly believe that his own relatives could not have wished it more beautiful, if they had been here".

"Certainly not, Madam," Mr Russell very contentedly concurred with her "and it is a pity that they could not be there, for such a nice funeral is always a great consolation for the bereaved.

Of course our funerals are not as magnificent as may be in London-" with an expectant glance to Wimsey. "But for this much nicer" this one prattled after Mrs Venables. "Here everything has still something personal." "Very true" the funeral undertaker concurred with him visibly relieved. "Well, the people in London certainly have three or four funerals every week". ] (Sayers 1934: 104. German translation 1980: 100).

Excerpt (6) is an overt translation, with the Third Space nature of the translation here deriving from the fact that large stretches of the dialogues in the original text that are marked for regional and social varieties as well as register-specific colloquiality are not and indeed cannot be matched in the 
translation because there are no equivalent dialects and registers in the receiving lingua-culture (cf. House 1977; 1981). The point to be made here is not that this is clearly not "an error" on the part of the translator, rather we are left with an insuperable difference, and thus with a Third Space phenomenon which in this case derives from sui generis intracultural and intralinguistic variation which is in principle untranslatable. In excerpt (6) we witness an interaction between the gentleman detective Lord Peter Wimsey, the village undertaker Mr Russell and the Rector's wife Mrs Venables, with the speech of the latter characters being marked by both regional and social varieties which is in marked contrast to the speech of the aristocratic detective. This linguistic spectrum is not (and cannot be) equivalently reproduced in the German translation - which thus finds itself in Third Space which here consists of a constructed linguistic neutrality devoid of dialectal traces.

Similarly, in the translation of the autobiography of the famous American physicist and Nobel prize winner Richard Feynman, Surely you're joking, Mr Feynman (1986), translated by H.J.Metzger as Sie belieben wohl zu scherzen, Mr Feynman (1987) in extract (7), the style level is shifted from a chatty informal narrative to a much more formal account of his lecturing tours.

(7) In Canada, they have a big association of physics students. They have meetings; they give papers and so on. One time the Vancouver chapter wanted to have me come and talk to them. The girl in charge of it arranged with my secretary to fly all the way to Los Angeles without telling me... One time a few years after I had won the Nobel Prize, some kids from the Irvine students' physics club came around and wanted me to talk.

In Kanada gibt es eine große Vereinigung von PhysikStudenten. Sie veranstalten Tagungen; es werden Referate gehalten und so weiter. Einmal wollte die Ortsgruppe von Vancouver, dass ich hinkäme und zu ihnen spräche. Das Mädchen, das dafür zuständig war, vereinbarte einen Termin mit meiner Sekretärin und flog die weite Strecke bis Los Angeles, ohne dass ich etwas davon erfuhr... Ein andermal, ein paar Jahre später, nachdem ich den Nobelpreis bekommen hatte, kamen ein paar Studenten vom Physik-Club in Irvine an und wollten, dass ich einen Vortrag hielt.

[In Canada there is a big union of physics students. They organize conferences; there are papers being held etc. Once the local Vancouver group wanted that I would come and would talk to them. The girl who was responsible for this, made an appointment with my secretary and flew the long haul to Los Angeles without me learning anything about it. Another time, a few years later, after I had received the No- 
bel Prize, a few students from the physics club in Irvine came and wanted that I give a paper.] (Feynman 1986: 276. German translation 1987: 401).

The consistently higher formality in this covert German translation in extract (7) does not result from the linguistic impossibility of constructing an equivalently informal text, rather it is a consequence of - conscious or unconscious cultural filtering on the part of the translator. The translation is moved to a Third Space: the use of, inter alia, the subjunctive and the overall syntactic complexity of the clauses which characterize this translation sets it apart from texts belonging to the German genre autobiography. The original was transformed in its translated guise into a far less colloquial, much more formal text reflecting the supposed dignity of the protagonist and the occasion described - a covert translation which is in stark contrast to the original's informality, chattiness and colloquiality.

Extract (8) is taken from yet another genre: a contemporary novel by last year's booker prize winner Kiran Desai The Inheritance of Loss (2006) translated by Robin Detje as Erbin des verlorenen Landes (2006). In extract (8) we witness the failure of the protagonist, an English-educated Indian judge, to teach his wife English and its consequence.

(8) "What is this?" he asked holding up the bread roll. Silence. "If you can't say the word, you can't eat it." More silence. $\mathrm{He}$ removed it from her plate. Later that evening, he snatched the Ovaltine from her tentative sipping. "And if you don't like it, don't drink it." He couldn't take her anywhere and squirmed when Mrs Singh waggled her finger at him and said: "Where is your wife, Mr Patel? None of this purdah business, I hope?" In playing her part in her husband's career, Mrs Singh had attempted to mimic what she considered a typical English woman's balance between briskly pleasant and firmly no-nonsense, and had thus succeeded in quashing the spirits of so many of the locals who prided themselves on being mostly nonsense.

„Was ist das?”, fragte er und hielt das Stück Brot hoch. Schweigen. „Wenn Du das Wort nicht weißt, darfst du es nicht essen". Noch mehr Schweigen. Er nahm es ihr vom Teller. Später am Abend entriss er ihr die Ovomaltine, bevor sie vorsichtig daran hatte nippen können. „Wenn du es nicht magst, dann trink es auch nicht." Er konnte sie nirgendwo hin mitnehmen und wand sich, wenn Mrs Singh den Finger hob und sagte: „Wo ist denn Ihre Frau, Mr. Patel. Das ist doch hoffentlich nicht so ein purdah-Zeugs?" Um ihre Rolle in Mr Singhs Karriere spielen zu können, hatte Mrs Singh versucht, sich ganz in das zu verwandeln, was sie für eine typische Engländerin hielt, freundlich forsch und allem Un- 
sinn abgeneigt, und so hatte sie viele der Einheimischen niedergewalzt, die stolz auf ihren Unsinn waren.

["What is that?" he asked and held the piece of bread up. Silence. "If you don't know the word, you're not allowed to eat it". More silence. He took it from her plate. Later in the evening he snatched the ovaltine from her before she had been able to take a careful nip. "If you don't like it, then don't drink it". He could take her nowhere with him and he squirmed, when Mrs Singh lifted her finger and said: "Where is your wife, Mr Patel? That is hopefully not such a purdah stuff?" In order to be able to play her role in $\mathrm{Mr}$ Singh's career, Mrs Singh had tried to completely change into what she assumed was a typical Englishwoman, friendlily pushy and averse to all nonsense, and so she had mowed down many of the natives who were proud of their nonsense.] (Desai 2006:171. German translation 2006:222)

Excerpt (8) is taken from an overt translation, in which the translator tries to mimic the language of the original and even leaves foreign words unchanged in the text to get the original's linguistic profile and "atmosphere" across and to instil in the reader of the German translation a sense of "foreignness'. However, as can be seen in (8) above, differences in the expression potential of the two languages (here the unavailability of the ing-form with its function of immediacy and its usefulness in congruent descriptions of actions), the translation does not match the sophisticated and original style of the original. For example, "he snatched the ovaltine from her tentative sipping" is very different from the more neutral, pale and pedestrian ["He snatched the ovaltine from her before she had been able to take a careful sip"] (a back Translation of the German sentence). Further, the expressivenes of the lexical items "squirmed" "waggled her finger", "firmly nonnonsense" is far from being matched in the stilted German wordings "wand sich", "den Finger hob", and "allem Unsinn abgeneigt". Further, in line with the expression potential of the German language, the translation is replete with so-called Modalpartikeln (modal particles) with which subtle shades of meaning are expressed - meanings which - as these linguistic means do not exist in English and not in this original text, are freely added by the translator (cf. e.g. "noch", "denn") . In all these cases we are confronted with a Third Space phenomenon. Its origin lies in the impossibility of achieving full stylistic equivalence: there is simply no one-to one match of the expressive potential of two language systems.

Finally, here is an entirely different type of translation as a Third Space phenomenon: the impossibility of bridging the gap between historically and culturally generated taboos in two societies. This can be illustrated with the case of the translation of a recent philosophical-political essay by Ted Honderich, After the terror (2002). Due to the political stance taken by the author, the first German translation (2002) was taken off the 
market shortly after its appearance, despite the fact that one of Germany's leading contemporary philosophers Jürgen Habermas had both recommended the publication of the book and had protested against its ban pointing out that the appearance of the book was not a problem in its original British context. A translated new edition by Thomas Fehlige and Beatrice Kobow (2003) followed after nearly two years had elapsed, "revised" and "newly translated", with a "Postscriptum without remorse" being added to the translation by the original author. The first translation had been an overt translation, i.e., a faithful quotation of the original, but as such it was denied access to the indigenous genre of German philosophical-political essays in which freedom of speech is limited in one particular area: the (supposed) expression of anti-semitism. The author of After the terror had violated against this taboo: he had expressed support for the moral right of Palestinian protest and resistance against Israeli occupation and land confiscation, which was taken as an expression of anti-semitism by members of the German public, and thus a breach of a taboo. For the translation this meant that it existed in a sort of limbo, and this limbo is, I would suggest, a particular version of Third Space, from which the translation could and indeed quickly was expelled. The second version of the translation was only permitted to exist together with an explanatory postscript that explicated its status. It appeared with a different, much less prestigious publishing house. This re-translation is, however, also clearly a Third Space phenomenon, as it stands alone in its critical stance in the German publishing landscape. Here now is a brief excerpt (9) to demonstrate what the offending lines were like in the original, that the translation faithfully renders them, and that the Third Space nature of the translation derives not from the plane of language and/or the context of situation - as was the case in extracts (1) to (8) - but from external politico-societal pressures.

(9) The principle of humanity, being serious and arguable, does not give an automatic verdict on all terrorism. It is a principle that takes account of the world in its differences. It struggles with facts and probabilities, with the difficulty of rationality. To my mind, still, it does issue one conclusion of a certain generality, this being about liberation-terrorism, terrorism to get freedom and power for a people when it is clear that nothing else will get it for them.

In dem ernst gemeinten und begründbaren Prinzip der Humanität gibt es keinen Mechanismus, der jeden Terrorismus sofort verurteilen würde. Das Prinzip berücksichtigt die Welt mit all ihren Unterschieden. Es ringt mit Tatsachen und Wahrscheinlichkeiten, mit der Schwierigkeit der Rationalität. Dennoch liefert es in meinen Augen eine Schlußfolgerung von gewisser Allgemeinheit, nämlich über den Befreiungsterrorismus, einen Terrorismus mit dem Ziel, einem 
Volk Freiheit und Einflu $\beta$ zu verschaffen, wenn es eindeutig ist, dass nichts anderes ihm dazu verhelfen wird.

[In the seriously meant and defensible principle of humanity there is no mechanism which would pass an immediate verdict on terrorism. The principle takes account of the world with all its differences. It struggles with facts and probabilities, with the difficulty of rationality. Still it supplies to my mind one conclusion of a certain generality, namely liberation-terrorism, a terrorism aiming at freedom and influence for a people, when it is clear that nothing else will help it gain these.] (Honderich 2002: 150-151. German translation 2003/2004: 231)

To sum up: I have argued that the translator in operating on written text singly and creatively constructs context as a Third Space phenomenon and enacts discourse ex post facto. Functional approaches to language such as systemic functional linguistics were given preference over other perspectives on context since their notion of context is more suitable for written text and for a theory of translation as Third Space re-contextualization. Recontextualization was defined as taking a text out of its original context placing it within a new set of relationships in Third Space. The distinction between overt and covert translational procedures was shown to reflect divergent ways of solving the translator's re-contextualization task: in overt translation, the original's context is reactivated alongside the new target context, such that two different discourse worlds are juxtaposed in the medium of the target language with the resulting Third Space resembling a sort of schizophrenic duality of a new order. In covert translation, the translator concentrates exclusively on the envisaged new target context, employing a cultural filter to cater to the imagined new addressees' context-derived communicative norms. Covert translation is more immediately affected by contextual differences. However, it is never possible to overcome these differences completely. Here too, then, the Third Space must do. We also saw that any strong hypothesis of linguistic relativity is to be replaced by a weaker one of linguistic-cultural relativity which, in covert translation, allows for processes of cultural filtering. However, it is a moot issue today whether such filtering and placing in Third Space is today still routinely undertaken, or indeed expected in the face of the ever more powerful influence of one particular language which is more equal than others: English as a global lingua franca. I will briefly discuss this issue in the following final part of this article. For reasons of space this part will be necessarily brief I refer the reader to the publications from a relevant project: "Verdecktes Übersetzen- Covert Translation", which has been funded by the German Science Foundation since 1999 (cf. the website of the Sonderforschungsbereich "Mehrsprachigkeit": www. uni-hamburg.de/fachbereicheeinrichtungen/sfb 538/pojekte.html). Further, my ideas about the nonrecontextualization and the relegation of translations from English into 
what I take the liberty of calling "First Space" are bound to be rather speculative at the present time.

\section{On the demise of translation as re-contextualization and Third Space}

Along with today's galloping progress of globalization, internationalization and communication technology which affects most aspects of contemporary life, there is a concomitant rise in the demand for texts which are simultaneously meant for recipients in many different linguistic and cultural contexts. These texts are either translated covertly or produced immediately as 'comparable texts' in different languages and cultural contexts. In the past, translators and text producers tended to routinely apply a cultural filter in such cases. Due to the current worldwide dominance of the English language as a lingua franca, a tendency towards 'cultural universalism' or 'cultural neutralism', which is really a drift towards Anglo-American norms, has now been set into motion. In the decades to come, the conflict between cultural universalism propelled by the need for both fast and global dissemination of information and culture specificity geared towards local, particular needs will become ever more marked. It is therefore plausible to hypothesize that much less cultural filtering in re-contextualization processes will occur in the future, and that many more 'contextually homogenized' First Space' translation texts will be produced as carriers of (hidden) Anglophone and West-European/North-Atlantic text norms. What I here mean by 'First Space' is of course a term created by analogy with the "First World" - First Space being like the First World a dominant, hegemonic entity. While the notion of Third Space as laid out in this article captures difficulties, bordering on impossibilities, of translatory action resulting from deep-seated linguistic and cultural incompatibilities in both overt and covert translation, which leave translations stranded somewhere in nowhereland, the notion of First Space implies the very opposite: Anglophone source texts move without difficulty from their Anglophone lingua-cultural context to any other context because their native norms are simply foisted upon the new environment. First space translations can therefore be conceived as a new kind of overt translation - overt in a very different sense from the original conception as discussed above, i.e., a translation where both source and target contexts were co-activated in recipients' minds so as to make them appreciate the original albeit in their own language. By contrast, First Space overt translations do not allow any co-activation, rather the target context is effortlessly taken over (hijacked, raped) with Anglophone text conventions and norms of communicative preferences being imported. Underneath their surface phenotypical appearance in the target language these translated texts are genotypically Anglophone ones.

While Anglophone influence in the area of lexis has long been acknowledged and bemoaned by many (cf. the rich literature on "Anglicisms"), a comparable impact at the levels of pragmatics and discourse has 
hardly been recognized. The effect of the shift in translation and multilingual text production towards neutral, but stealthily progressing Anglophone contexts in influential genres, is therefore an important research area for the future, where diachronic corpus-based investigations into hitherto unidentified problems should be given preference. One first step in this direction is taken by the project "Verdecktes Übersetzen - Covert Translation", which has investigated Anglophone influence on German, French and Spanish translation and comparable texts (cf. e.g. Baumgarten et al. 2004; House and Rehbein 2004; Baumgarten 2007; Böttger 2004; 2007; Bührig et al. in press; House 2003; 2004a; 2006a; 2007), and has conducted quantitative and qualitative diachronic analyses on the basis of multilingual corpora of texts (comprising about 1 million words) from popular science and economic genres as well as interviews, newspaper and other background material. The analyses show that German communicative preferences - but, interestingly, not French and Spanish ones - have indeed undergone a process of change over the past 25 years. Particularly vulnerable are functional categories such as personal pronouns, co-ordinate conjunctions, pronominal adverbials, and other connectors, which function as triggers for changes in text conventions in both translations and comparable texts. The result is a general - and new - tendency towards colloquialization, personalization and oralization in German texts. Such a tendency has long characterized Anglophone norms in the two genres under investigation, but is very different in the context of the German tradition, where a more 'scientific', more 'serious' norm was traditionally followed such that e.g. in popular science translations from English, a routinely employed cultural filter enabled German readers to be informed in the more detached, 'objective' manner they are used to rather than the lightly entertaining, colloquial tone of the English originals. All this, it seems, is now in a process of change given Anglophone norm dominance and the concomitant denial of cultural filtering in genres where such filtering was routinely undertaken to account for differences in culture-conditioned text norms. However, it is far too early to claim that translations from English are steadily moving out of Third Space into Anglophone First Space, such that they will be German, French or Spanish etc. only on the linguistic surface while 'underneath' stealthily embodying Anglophone norms. Much more research with many different genres and different languages is needed to substantiate the hypotheses of First Space Anglophone domination I have here (tentatively) suggested.

\section{Bibliography}

\section{Primary Texts}

Bond, Michael (1958). A Bear called Paddington. London: Collins.

Bond, Michael (1968). Paddington unser kleiner Bär. Übersetzung von Brigitte von Mechow und Peter Kent. München:Burnett.

Desai, Kiran (2006).The Inheritance of Loss. London: Penguin Books. 
Desai, Kiran (2006). Erbin des verlorenen Landes. Übersetzung von Robin Detje. Berlin: Berlin Verlag.

Feynman, Richard (1986). “ Surely You're Joking, Mr. Feynman!” New York: Bantam Books.

Feynman, Richard (1987). "Sie Belieben Wohl zu Scherzen, Mr. Feynman!“ Übersetzung von HansJoachim Metzger. München: Piper.

Honderich, Ted (2002). After the Terror. Edinburgh: Edinburgh University Press.

Honderich, Ted (2003/2004). Nach dem Terror. Ein Traktat. Erweiterte, revidierte und neu übersetzte Ausgabe von Thomas Fehrige und Beatrice Kobow. Neu-Isenburg: Melzer Verlag.

Ives, Penny (1990). Mrs Christmas. London:Hamish Hamilton.

Ives, Penny (1990). Morgen kommt die Weihnachtsfrau. Übersetzung von Ishel U. Eichler. Hamburg: Carlsen.

Robinson, Barbara (1972). The Best Christmas Pageant Ever. New York: Harper Collins.

Robinson, Barbara (1972). Hilfe die Herdmanns kommen. Übersetzung von Nele und Paul Maar. Hamburg: Oetinger.

Sayers, Dorothy (1934). The Nine Taylors. London: Gollancz.

Sayers, Dorothy (1980). Der Glockenschlag. Übersetzung von Otto Bayer. Reinbek: Rowohlt.

\section{Secondary texts}

Baker, Mona (2007). Translation and Conflict. London: Routledge.

Batchelor, Kathryn (2008). "Third Spaces, Mimicry and Attention to Ambivalence". The Translator 14(1), 51-70.

Bateson, Gregory (1972). Steps to an Ecology of Mind. New York. Ballantine Books.

Baumgarten, Nicole (2007). "Converging conventions? Macrosyntactic conjunction with English and and German und". Text \& Talk 27(2), 139-170.

Baumgarten, Nicole, Juliane House \& Julia Probst (2004). "English as lingua franca in covert translation processes". The Translator 10(1), 83-108.

Benjamin, Walter (1972). "Die Aufgabe des Übersetzers". W. Benjamin Gesammelte Schriften Bd. IV/1. Frankfurt/Main: Suhrkamp. Vorwort des Übersetzers.(W. Benjamin) zur Übersetzung von Charles Baudelaire's Tableaux Parisien, 9-21.

Bhabha, Homi (1990). "The Third Space: Interview with Homi Bhabha". J. Rutherford (ed.) (1990). Identity: Community, Culture, Difference. London: Lawrence \& Wishart, 207-221.

Bhabha, Homi (1994). The Location of Culture. London: Routledge.

Biber, Douglas (1988). Variation Across Speech and Writing. Cambridge: Cambridge University Press.

Böttger, Claudia (2004). "Genre-mixing in Business Communication". J.House \&J.Rehbein, (eds)(2004), 115-132.

Böttger, Claudia (2007). Lost in translation? An analysis of the influence of English as the lingua franca of multilingual business communication. Hamburg: Kovac.

Bührig, Kristin, Juliane House \& Jan ten Thije (eds) (in press). Translatory Action and Intercultural Communication. Manchester: St. Jerome.

Calzada Perez, Maria (2003). (ed.) Apropos of Ideology - Translation Studies on Ideology - Ideologies in Translation Studies. Manchester: St. Jerome.

Clifford, James (1997). Routes. Travel and Translation in the Late Twentieth Century. Cambridge, MA: Harvard University Press.

Goffman, Erving (1974). Frame Analysis. New York. Harper and Row.

Gupta, A \& J. Ferguson (1997) (eds). Culture, Power, Place: Ethnography at the end of an era. Durham, NC: Duke University Press.

Halliday, Michael A.K. (rev. by C.M.I.M. Matthiessen) (2004). An Introduction to Functional Grammar. London: Arnold.

Hatim, Basil \& Ian Mason (1997). The Translator as Communicator. London: Routledge.

Hermans, Theo (1985). The Manipulation of Literature. London: Croom Helm.

Holliday, Adrian (1999). "Small Cultures". Applied Linguistics 20(2), 237-264.

House, Juliane (1973). Theoretical Aspects of Translation. Washington, DC: ERIC Educational Research Information Centre. 
House, Juliane (1977/1981). A Model for Translation Quality Assesment. 2nd edition. Tübingen: Narr.

House, Juliane (1997). Translation Quality Assessment: A Model Revisited. Tübingen: Narr.

House, Juliane (1998). Politeness and Translation. L.Hickey(ed.). The Pragmatics of Translation. Clevedon: Multilingual Matters, 54-72.

House, Juliane (2000). Linguistic Relativity and Translation. M. Puetz \& M. Verspoor (eds). Explorations in Linguistic Relativity. Amsterdam: Benjamins, 69-88.

House, Juliane (2001a). How do we know when a translation is good? E. Steiner \& C. Yallop (eds), $127-160$.

House, Juliane (2001b). "Culture-specific elements in translation". H. Kittel, Harald et al. (eds) Übersetzung Translation Traduction. An International Encyclopedia of Translation Studies. Berlin/New York: de Gruyter, 494-504.

House, Juliane (2003). "English as a lingua franca: A threat to multilingualism?". Journal of Sociolinguistics 7(4), 556-579.

House, Juliane (2004a). "English as a lingua franca and its influence on texts in other European languages". G.Garzone \& A.Cardinaletti(eds). Lingua, Mediazione Linguistica $e$ Interferenza. Milano: Franco Angeli, 21-47.

House, Juliane (2004b). "Linguistic Aspects of the translation of children's books". H. Kittel, Harald et al. (eds). Übersetzung Translation Traduction. An International Encyclopedia of Translation Studies. Berlin/New York: de Gruyter, 683-697.

House, Juliane (2005). "Politeness in Germany-Politeness in Germany?". L. Hickey,\& M. Stewart (eds). Politeness in Europe. Clevedon: Multilingual Matters, 13-28.

House, Juliane (2006a). "Text and Context in Translation". Journal of Pragmatics 38, 338-358.

House, Juliane (2006b). "Communicative Styles in English and German". European Journal of English Studies 10, 249-267.

House, Juliane (2007). "Covert Translation and Language Contact and Language Change". The Chinese Translators Journal 28, 17-26.

House, Juliane \& Jochen Rehbein (eds)(2004). Multilingual Communication. Amsterdam: Benjamins.

Koller, Werner (1995). "The Concept of Equivalence and the Object of Translation Studies". Target 7, 191-222.

Malinowsli, Bronislaw (1935). Coral Gardens and Their Magic (II). London: Allen and Unwin.

Mason, Ian (1994). "Discourse, Ideology and Translation". R. de Beaugrande, A. Shunnaq \& M. Helmy Heliel (eds). Language, Discourse and Translation in the West and Middle East. Amsterdam: Benjamins, 23-34.

Ortega y Gasset, José (1937/1956). Miseria y Esplendor de la Traducción / Elend und Glanz der Übersetzung. München: Langewiesche-Brandt.

Robinson, Douglas (1997). Translation and Empire. Manchester: St. Jerome.

Schleiermacher, Friedrich (1973/1813). "Über die verschiedenen Methoden des Übersetzens". H-J. Störig (ed.). Das Problem des Übersetzens. Stuttgart. Goverts, 38-70.

Steiner, Erich \& Colin Yallop (eds) (2001). Exploring translation and multilingual text production: Beyond content. Berlin:Mouton.

Sperber, Dan (1996). Explaining Culture. A Naturalistic Approach. Oxford: Blackwell.

Venuti, Lawrence (1995). The Translator's Invisibility. London: Routledge.

Widdowson, Henry (2004). Text, Context, Pretext. Oxford: Blackwell.

Wolf, Michaela (2000). "The Third Space in Postcolonial Representation". S. Simon \& P. St.Pierre (eds). Changing the Terms: Translating in the Postcolonial Era. Ottawa: University of Ottawa Press, 127-146. 